\title{
PERSEPSI PEGAWAI TERHADAP IMPLEMENTASI MANAJEMEN TALENTA DI ORGANISASI PEMERINTAHAN
}

\author{
EMPLOYEE PERCEPTION OF TALENT MANAGEMENT IMPLEMENTATION IN GOVERNMENT \\ ORGANIZATIONS
}

\author{
Ahmad Rifai" ${ }^{* 1}$, M. Syamsul Maarif ${ }^{*}$, dan Anggraini Sukmawati**) \\ ${ }^{*}$ Sekolah Bisnis, IPB University \\ Jl. Raya Padjajaran, Bogor 16151, Indonesia \\ **) Departemen Manajemen, Fakultas Ekonomi dan Manajemen, IPB University \\ Jl. Agatis Kampus IPB Dramaga, Bogor 16680, Indonesia
}

\begin{abstract}
This study aims to analyze employee perceptions of the implementation of talent management in the Ministry of Finance, as well as to analyze the relationship between the profile of respondents and the four stages of talent management. The population in this study was 80,996 employees within the Ministry of Finance and the sample size was 408 employees who were determined by using stratified random sampling technique. Data analysis using a quantitative approach includes validity and reliability tests, averaging, two boxes, cross tabulation, and different tests. The results showed that employees' perceptions of the implementation of talent management at the Ministry of Finance were good, but improvements were needed in 7 indicators: (1) understanding of the 9 boxes for mapping employees, (2) searching for talented people by organizations, (3) information criteria to become talent, (4) information about employees who are determined to be talents, (5) motivation of leaders to develop employee careers, (6) objective assessment of career development, and (7) facilities for employee competency development programs. There is a relationship between respondents and these 7 indicators. Meanwhile, there are differences in respondents' perceptions with these 7 indicators. The managerial implications that can be applied are the socialization of talent management to all employees, employee development programs to improve competence and careers, and paying attention to the profile of respondents in developing talent management.
\end{abstract}

Keywords: career development, competency, manpower planning, Ministry of Finance, talent mapping

\begin{abstract}
Abstrak: Penelitian ini bertujuan untuk menganalisis persepsi pegawai terhadap implementasi manajemen talenta di Kementerian Keuangan, serta menganalisis hubungan profil responden dengan empat tahapan manajemen talenta. Jumlah populasi pada penelitian ini adalah 80.996 pegawai Kementerian Keuangan dan jumlah sampel adalah 408 pegawai yang ditentukan dengan teknik pengambilan sampel stratified random sampling. Analisis data menggunakan pendekatan kuantitatif meliputi uji validitas dan reabilitas, rataan, two boxes, tabulasi silang, dan uji beda. Hasil penelitian menunjukkan bahwa persepsi pegawai terhadap implementasi manajemen talenta di Kementerian Keuangan sudah baik, tetapi diperlukan perbaikan pada 7 indikator, yaitu (1) pemahaman tentang 9 boks pemetaan pegawai, (2) pencarian orang-orang bertalenta oleh organisasi, (3) informasi tentang kriteria menjadi talent, (4) informasi tentang pegawai yang ditetapkan menjadi talent, (5) motivasi pimpinan untuk mengembangkan karier pegawai, (6) penilaian pengembangan karier secara objektif, serta (7) fasilitas program pengembangan kompetensi pegawai. Terdapat hubungan antara responden dengan 7 indikator tersebut. Terdapat perbedaan persepsi responden dengan 7 indikator tersebut. Implikasi manajerial yang dapat diterapkan yaitu sosialisasi manajemen talenta kepada seluruh pegawai, program pengembangan pegawai untuk meningkatkan kompetensi dan karier, serta memperhatikan profil responden dalam mengembangkan manajemen talenta
\end{abstract}

Kata kunci: kementerian keuangan, kompetensi, pemetaan talenta, pengembangan karir, perencanaan pegawai

${ }^{1}$ Corresponding author:

Email: rifai.ap@gmail.com 


\section{PENDAHULUAN}

Manajemen talenta merupakan proses untuk mengantisipasi dan memenuhi kebutuhan organisasi melalui bakat di dalam pekerjaan yang strategis (Cappelli dan Keller, 2014). Melalui pengelolaan manajemen talenta yang baik, organisasi diharapkan mampu meningkatkan keuntungan non-finansial seperti daya tarik perusahaan dan motivasi karyawan, serta dapat memberikan dampak yang tinggi serta keuntungan perusahaan secara signifikan (Rachmawati, 2012). Pella dan Inayati (2011) menguraikan kerangka kerja manajemen talenta meliputi perekrutan dan seleksi, orientasi, manajemen kinerja, pengakuan dan retensi, pendidikan dan pelatihan, serta pengembangan kaderisasi.

Mehta (2011) dalam penelitiannya menjelaskan bahwa manajemen bakat berpusat pada aktivitas yang digunakan untuk memaksimalkan kinerja organisasi dimana komponen inti dari MT meliputi strategic workforce planning, total talent acquisition, employee development, performance development, dan succession planning. Farooq et al. (2016) dalam penelitiannya yang bertujuan menganalisis implementasi manajemen bakat di Uganda menunjukkan hasil bahwa model pengukuran yang terdiri dari talent identification, talent development, talent culture, dan talent retention valid dan andal digunakan dalam praktik manajemen bakat. Ali et al. (2019) dalam penelitiannya mengatakan bahwa strategi manajemen talenta yang diterapkan PT. Unilever Indonesia Tbk. meliputi attracting, developing dan retaining. Dewi (2020) dalam penelitiannya terhadap praktik manajemen talenta di Pemerintah Provinsi Bali menjelaskan bahwa manajemen talenta yang diterapkan meliputi perencanaan, rekrutmen, pengembangan kompetensi, pengembangan karir, promosi, perencanaan suksesi untuk mengisi posisi pemimpin tinggi primer dalam rangka mewujudkan pemimpin berkinerja tinggi, yang gesit yang ditandai dengan nilai-nilai sosio budaya.

Manajemen talenta tidak hanya diterapkan pada organisasi swasta, tetapi juga pada organisasi publik, termasuk Kementerian Keuangan (Kemenkeu). Dalam mengemban otoritas pengelolaan bidang fiskal dan kekayaan negara, Kemenkeu mempunyai 5 (lima) misi dimana salah satunya adalah "Mengembangkan proses bisnis inti berbasis digital dan pengelolaan Sumber Daya Manusia yang adaptif sesuai kemajuan teknologi." Misi tersebut dirumuskan karena Kemenkeu merasa bahwa
Sumber Daya Manusia (SDM) memiliki peranan penting, penentu keberhasilan, dan memberikan nilai tambah, serta keunggulan kompetitif bagi organisasi (Kemenkeu, 2016). Untuk meningkatkan kualitas pegawainya, Kemenkeu menerapkan manajemen talenta yang dikembangkan untuk mencari, mengelola, mengembangkan, dan mempertahankan pegawai terbaik Kemenkeu yang dipersiapkan sebagai calon pemimpin masa depan untuk mendukung pencapaian visi, misi, dan strategi organisasi (Kemenkeu, 2016). Tahapan-tahapan persiapan yang dilakukan Kemenkeu meliputi penyusunan inisiatif strategis, identifikasi pemimpin masa depan, perolehan kompetensi, dan tujuan (Kemenkeu, 2017). Berdasarkan hasil wawancara pendahuluan, didapatkan hasil bahwa pegawai belum memahami penerapan manajemen talenta di Kementerian Keuangan. Selanjutnya, pengelola manajemen talenta di Kementerian Keuangan menjelaskan bahwa sosialisasi mengenai manajemen talenta belum dilakukan secara optimal. Saat ini, sosialisasi baru dilakukan melalui landing page yang berisi peraturan tentang manajemen talenta di Kementerian Keuangan.

Revolusi industri 4.0 telah membawa pengaruh terhadap seluruh aspek kehidupan, termasuk sistem pemerintahan, termasuk Indonesia. Pemerintah dituntut untuk menyesuaikan diri untuk menyambut Indonesia Emas 2045, melalui perwujudan Smart ASN yang memiliki kompetensi, kinerja, dan profesionalisme yang tinggi. Selain itu, Smart ASN diharapkan dapat menjadi digital talent dan digital leader yang siap mendukung transformasi birokrasi digital (Komara, 2019). Digital talent merupakan talenta yang mempunyai gabungan antara hard digital skills dan soft digital skills yang mengedepankan pemikiran digital (Nair, 2019). Sementara itu, digital leadership merupakan kepemimpinan yang tanggap dan mampu menangani antarhierarki, serta berfokus pada inovasi melalui pendekatan yang kooperatif (Oberer dan Erkollar, 2018).

Pada dekade terakhir ini, organisasi dihadapkan pada fenomena komposisi tenaga kerja yang memiliki rentang usia yang cukup lebar karena setiap generasi memiliki keunikan tersendiri yang terkadang dapat menimbulkan berbagai masalah. Oleh karena itu, organisasi perlu berpikir lebih strategis dan berfokus pada solusi yang mampu menjadikan perbedaan ini menjadi kekuatan yang memiliki nilai tambah untuk mendongkrak kinerja organisasi. Betz (2019) membagi 
generasi menjadi empat kelompok, yaitu generasi baby boom (1940-1959), generasi X (1960-1979), generasi Y (1980-1994), dan generasi Z (1995-2010). Fenomena ini juga terjadi di Kemenku dimana 41 persen pegawai adalah generasi millennial, 29 persen adalah generasi X, 26 persen adalah generasi Z, dan 4 persen adalah generasi baby boomer. Hal ini menuntut Kemenkeu untuk mengelola talenta dengan tepat untuk meningkatkan kinerja mereka dan mendukung tujuan organisasi. Selain itu, organisasi juga perlu memperhatikan kedudukan/jabatan dari pegawai, lokasi kantor, latar belakang pendidikan, jenis kelamin, serta unit eselon I para pegawai.

Berdasarkan penjelasan maka perlu untuk dilakukan penelitian untuk menganalisis persepsipegawai terhadap implementasi manajemen talenta di Kementerian Keuangan yang meliputi strategic workfoce planning, talent identification, talent development, dan talent retention. Selain itu, penelitian ini bertujuan untuk menganalisis hubungan serta perbedaan persepsi antara profil responden (jenis kelamin, kedudukan/ jabatan, tahun kelahiran, unit eselon I, domisili kantor, serta pendidikan terakhir) dengan empat tahapan manajemen talenta tersebut. Akhirnya, penelitian ini dapat memberikan alternatif strategi pengembangan manajemen talenta di organisasi pemerintah.

\section{METODE PENELITIAN}

Uji validitas dan reliabilitas pada penelitian ini dilakukan dengan menggunakan SPSS. Indikator penelitian dikatakan valid jika nilai r-hitung lebih besar dari r-tabel atau $p$-value di bawah 0.05 . Uji reliabilitas dilakukan dengan uji Cronbach Alpha dimana koefisien Cronbach Alpha minimal 0,70. Selanjutnya dilakukan statistik korelasi untuk mengetahui kuatnya hubungan antardua variabel atau lebih (Sugiyono, 2017).

Analisis data dalam penelitian ini menggunakan statistik deskriptif dan statistik inferensial menggunakan SPSS. Analisis statistik parametrik yang digunakan adalah uji-t sampel independen, uji ANOVA, dan uji Tukey Post-Hoc.Uji-t digunakan untuk menguji apakah ratarata dua populasi sama atau berbeda nyata (Amrhein et al. 2019). Sementara itu, Analysis of Variance (ANOVA) adalah metode analisis multivariat untuk membedakan rata-rata lebih dari dua kelompok data dengan membandingkan varians. Selanjutnya dilakukan uji Tukey Post-Hoc untuk mengetahui perbandingan nilai rata-rata yang memiliki perbedaan yang signifikan antara satu kelompok dengan kelompok lainnya (Mishra et al. 2019).

Untuk mengetahui hubungan antara profil responden dengan variabel penelitian, dilakukan analisis tabulasi silang (crosstab analysis) menggunakan uji Chi-Squre Test. Jika Asymp. Sig (2-sided) Chi-Square $<\alpha$ maka terdapat hubungan antarvariabel tersebut. Selanjutnya, untuk mengetahui sebaran persepsi responden, digunakan top and bottom two boxes. Top two boxes dilakukan dengan menggabungkan responden yang setuju (skor 4) dan sangat setuju (skor 5) dibagi jumlah responden. Bottom two boxes dilakukan dengan menggabungkan responden yang tidak setuju (skor 2) dan sangat tidak setuju (skor 1) dibagi jumlah responden. Responden yang cukup setuju (skor 3) diasumsikan cenderung setuju sehingga digabungkan dalam top two boxes (Anggelina dan Japarianto 2014). Jumlah populasi pada penelitian ini adalah 80.996 pegawai. Sampel penelitian ditentukan menggunakan rumus Isaac dan Michael dengan tingkat kesalahan adalah 5 persen sehingga diperoleh jumlah sampel sebanyak 383 pegawai. Teknik penentuan sampel menggunakan proportionate stratified random sampling (Sugiyono, 2017) berdasarkan kedudukan/ jabatan pegawai, yaitu 1 orang pejabat eselon II, 8 orang pejabat eselon III, 42 orang pejabat eselon IV, dan 332 orang non-pejabat struktural.

Skala yang digunakan dalam penelitian ini adalah Skala Likert dengan setiap pilihan jawaban akan diberi skor $1-5$, yaitu $1=$ sangat tidak setuju, $2=$ tidak setuju, $3=$ ragu-ragu, 4= setuju, 5=sangat setuju (Sugiyono 2017). Adapun variabel dan indikator pada penelitian ini adalah sebagaimana Tabel 1. Kerangka pemikiran penelitian ini adalah sebagaimana Gambar 1. Sementara itu, hipotesis yang dibangun pada penelitian ini adalah sebagai berikut:

H1: terdapat hubungan antara variabel strategic workforce planning dengan talent identification.

$\mathrm{H} 2$ : terdapat hubungan antara variabel strategic workforce planning dengan talent development.

H3: terdapat hubungan antara variabel strategic workforce planning dengan talent retention.

H4: terdapat hubungan antara variabel talent identification dengan talent development.

H5: terdapat hubungan antara variabel talent identification dengan talent retention.

H6: terdapat hubungan antara variabel talent development dengan talent retention. 
TabeI 1. HasiI matriks IFE

\begin{tabular}{|c|c|c|c|}
\hline Variabel & Definisi & Simbol & Indikator \\
\hline \multirow{3}{*}{$\begin{array}{l}\text { Strategic Workforce } \\
\text { Planning (SP) } \\
\text { (Mehta, 2011; } \\
\text { Kemenkeu, 2017) }\end{array}$} & \multirow{3}{*}{$\begin{array}{l}\text { Tahap untuk } \\
\text { mengidentifikasi } \\
\text { kebutuhan dan tujuan } \\
\text { dari organisasi }\end{array}$} & SP1 & $\begin{array}{l}\text { Strategi manajemen talenta (MT) mengacu pada tujuan } \\
\text { organisasi }\end{array}$ \\
\hline & & SP2 & Strategi MT sesuai dengan budaya organisasi \\
\hline & & SP3 & Strategi MT sesuai dengan proses bisnis organisasi \\
\hline \multirow{7}{*}{$\begin{array}{l}\text { Talent Identification } \\
\text { (TI) } \\
\text { (Mehta, 2011; } \\
\text { Kemenkeu, 2017; } \\
\text { Farooq et al. 2016) }\end{array}$} & \multirow{7}{*}{$\begin{array}{l}\text { Proses penetapan } \\
\text { jabatan target dan } \\
\text { jumlah kebutuhan } \\
\text { talent yang fokus } \\
\text { pada perolehan } \\
\text { bakat total dan } \\
\text { mengintegrasikannya }\end{array}$} & TI1 & Penilaian talent memanfaatkan alat penilaian yang tersedia \\
\hline & & $\mathrm{TI} 2$ & Pemahaman 9 boks pemetaan pegawai \\
\hline & & $\mathrm{TI} 3$ & Pimpinan memahami kinerja pegawai untuk bertransformasi \\
\hline & & TI4 & Perencanaan talent telah dipersiapkan tahun sebelumnya \\
\hline & & TI5 & $\begin{array}{l}\text { Organisasi mencari orang berbakat untuk menempati posisi } \\
\text { penting dalam organisasi }\end{array}$ \\
\hline & & TI6 & $\begin{array}{l}\text { Tersedia informasi terbuka tentang kriteria pegawai yang } \\
\text { ditetapkan menjadi talent }\end{array}$ \\
\hline & & TI7 & $\begin{array}{l}\text { Tersedia informasi terbuka tentang pegawai yang ditetapkan } \\
\text { menjadi talent }\end{array}$ \\
\hline \multirow{6}{*}{$\begin{array}{l}\text { Talent Development } \\
\text { (TD) } \\
\text { (Mehta, 2011; } \\
\text { Kemenkeu, 2017; } \\
\text { Farooq et al. 2016; } \\
\text { Pella dan Inayati, } \\
\text { 2011) }\end{array}$} & \multirow{6}{*}{$\begin{array}{l}\text { Program pengembangan } \\
\text { yang akan diberikan } \\
\text { untuk meningkatan } \\
\text { keterampilan dan } \\
\text { kemajuan karier }\end{array}$} & TD1 & Motivasi pimpinan untuk pengembangan karier \\
\hline & & TD2 & $\begin{array}{l}\text { Pimpinan menilai kebutuhan pengembangan karier secara } \\
\text { objektif }\end{array}$ \\
\hline & & TD3 & Pimpinan mendorong pembelajaran \\
\hline & & TD4 & Tersedia mentor untuk pengembangan kompetensi tertentu \\
\hline & & TD5 & $\begin{array}{l}\text { Fasilitas program pengembangan untuk meningkatkan } \\
\text { kompetensi }\end{array}$ \\
\hline & & TD6 & Pimpinan mendorong pengembangan karier \\
\hline \multirow{4}{*}{$\begin{array}{l}\text { Talent Retention } \\
\text { (TR) } \\
\text { (Mehta, 2011; } \\
\text { Kemenkeu, 2017; } \\
\text { Farooq et al. 2016; } \\
\text { Pella dan Inayati, } \\
\text { 2011) }\end{array}$} & \multirow{4}{*}{$\begin{array}{l}\text { Penghargaan } \\
\text { kepada talent untuk } \\
\text { meningkatkan motivasi } \\
\text { dan komitmen } \\
\text { agar menunjukkan } \\
\text { kompetensi dan kinerja } \\
\text { optimal }\end{array}$} & TR1 & Organisasi menghargai kinerja \\
\hline & & TR2 & Penghargaan yang diberikan sesuai dengan kinerja \\
\hline & & TR3 & Tetap bertahan untuk waktu yang lama pada unit saat ini \\
\hline & & TR4 & Semakin termotivasi untuk berkontribusi pada unit \\
\hline
\end{tabular}

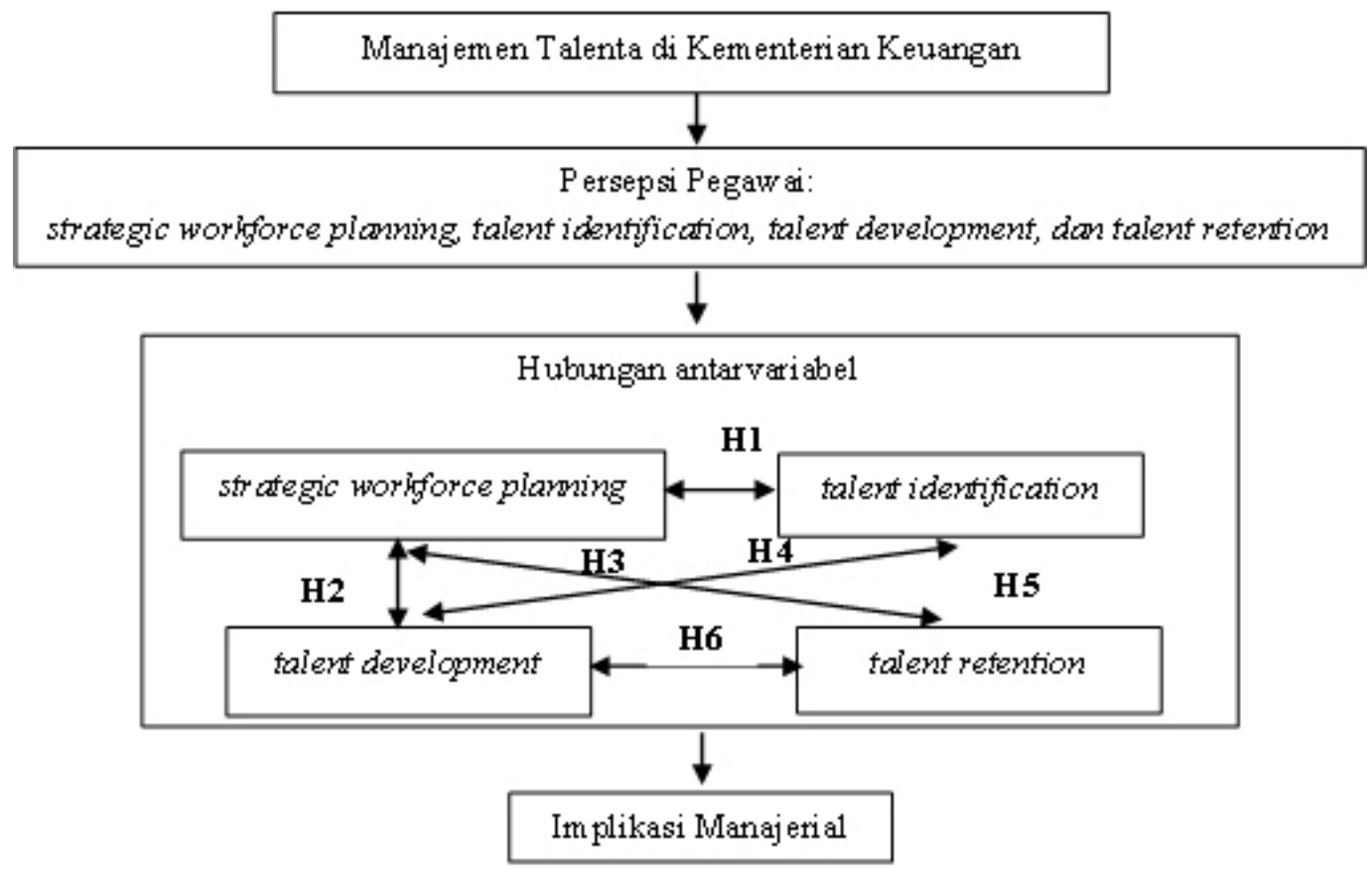

Gambar 1. Kerangka pemikiran penelitian 


\section{HASIL}

Jumlah populasi pada penelitian ini adalah 80.996 pegawai Kementerian Keuangan. Komposisi pegawai di Kementerian Keuangan terdiri dari 55.501 pegawai laki-laki dan 25.495 pegawai perempuan. Dari sisi kedudukan/jabatan, yaitu 217 pejabat eselon II, 1.741 pejabat eselon III, 8.971 pejabat eselon IV, dan 70.051 non-pejabat struktural. Dari segi generasi, sebanyak 3.240 merupakan generasi Baby Boomer, 23.489 Generasi X, 33.208 Generasi Y, dan 21.059 Generasi Z. Sementara itu, dari sisi golongan, 4 orang merupakan pegawai golongan I, 35.638 golongan II, 38.068 golongan III, dan 7.286 golongan IV.

\section{Profil Responden Penelitian}

Jumlah responden dalam penelitian ini adalah sebanyak 408 responden. Profil responden dikategorikan berdasarkan jenis kelamin, kedudukan/jabatan, tahun kelahiran, unit eselon I, domisili kantor, serta pendidikan terakhir sebagaimana pada Tabel 2. Mayoritas responden adalah pegawai laki-laki sebanyak 67,16 persen, berdasarkan kedudukan/ jabatan didominasi oleh non-pejabat struktural sebesar 85,05 persen. Selanjutnya, berdasarkan kedudukan/ jabatan sudah memenuhi jumlah yang ditetapkan, yaitu 1 orang pejabat eselon II (seharusnya 1 orang), 8 orang pejabat eselon III (seharusnya 8 orang), 52 orang pejabat eselon IV (seharusnya 42 orang), dan 347 orang non-pejabat struktural. Berdasarkan tahun kelahiran, responden didominasi oleh pegawai dengan tahun kelahiran 1987 s.d. 1994 sebesar 44,12 persen. Berdasarkan unit eselon I, responden didominasi oleh pegawai yang berasal dari DJP sebesar 43,87 persen. Berdasarkan lokasi kantor, sebesar 84,07 persen pegawai berkantor di Jawa. Sementara itu, berdasarkan pendidikan terakhir, responden dengan pendidikan terakhir S1/Sederajat mendominasi penelitian ini, yaitu sebesar 54,66 persen.

\section{Uji Validitas dan Uji Reliabilitas}

Berdasarkan analisis faktor menggunakan SPSS, didapatkan hasil bahwa seluruh indikator memiliki nilai di atas 0,30 . Sementara itu, berdasarkan uji reliabilitas didapatkan hasil bahwa seluruh variabel penelitian memiliki nilai Cronbach alpha lebih dari 0,70. Oleh karena itu, dapat disimpulkan bahwa variabel penelitian valid dan reliabel.
TabeI 2. Profil responden penelitian

\begin{tabular}{|c|c|c|c|}
\hline Karakteristik & $\begin{array}{c}\text { Frekuesi } \\
(\mathrm{n}=408)\end{array}$ & $\begin{array}{c}\text { Persentase } \\
(\%)\end{array}$ & $\begin{array}{c}\text { Persentase } \\
\text { Kumulatif } \\
(\%)\end{array}$ \\
\hline \multicolumn{4}{|l|}{ Jenis Kelamin } \\
\hline Laki-laki & 274 & 67,16 & 67,16 \\
\hline Perempuan & 134 & 32,84 & 100,00 \\
\hline \multicolumn{4}{|l|}{ Kedudukan/Jabatan } \\
\hline Pejabat Eselon II & 1 & 0,25 & 0,25 \\
\hline Pejabat Eselon III & 8 & 1,96 & 2,21 \\
\hline Pejabat Eselon IV & 52 & 12,75 & 14,95 \\
\hline $\begin{array}{l}\text { Non-Pejabat } \\
\text { Struktural }\end{array}$ & 347 & 85,05 & 100,00 \\
\hline \multicolumn{4}{|l|}{ Tahun Kelahiran } \\
\hline$<1960$ & 2 & 0,49 & 0,49 \\
\hline 1960 s.d. 1969 & 12 & 2,94 & 3,43 \\
\hline 1970 s.d. 1980 & 84 & 20,59 & 24,02 \\
\hline 1980 s.d. 1986 & 104 & 25,49 & 49,51 \\
\hline 1987 s.d. 1994 & 180 & 44,12 & 93,63 \\
\hline > 1994 & 26 & 6,37 & 100,00 \\
\hline \multicolumn{4}{|l|}{ Unit Eselon I } \\
\hline Setjen & 6 & 1,47 & 1,47 \\
\hline DJA & 11 & 2,70 & 4,17 \\
\hline DJP & 179 & 43,87 & 48,04 \\
\hline DJBC & 19 & 4,66 & 52,70 \\
\hline $\mathrm{DJPb}$ & 20 & 4,90 & 57,60 \\
\hline DJKN & 6 & 1,47 & 59,07 \\
\hline DJPK & 6 & 1,47 & 60,54 \\
\hline DJPPR & 2 & 0,49 & 61,03 \\
\hline Itjen & 5 & 1,23 & 62,25 \\
\hline BKF & 2 & 0,49 & 62,75 \\
\hline ВPРК & 152 & 37,25 & 100,00 \\
\hline \multicolumn{4}{|l|}{ Lokasi Kantor } \\
\hline Jawa & 343 & 84,07 & 84,07 \\
\hline Sumatera & 25 & 6,13 & 90,20 \\
\hline Kalimantan & 11 & 2,70 & 92,89 \\
\hline Bali-NTT-NTB & 4 & 0,98 & 93,87 \\
\hline Sulawesi & 24 & 5,88 & 99,75 \\
\hline Papua & 1 & 0,25 & 100,00 \\
\hline \multicolumn{4}{|l|}{$\begin{array}{l}\text { Pendidikan } \\
\text { Terakhir }\end{array}$} \\
\hline S3 & 3 & 0,74 & 0,74 \\
\hline S2 & 106 & 25,98 & 26,72 \\
\hline $\mathrm{S} 1 /$ Sederajat & 223 & 54,66 & 81,37 \\
\hline D3 & 59 & 14,46 & 95,83 \\
\hline D1 & 17 & 4,17 & 100,00 \\
\hline
\end{tabular}




\section{Uji Korelasi}

Hasil uji korelasi menunjukkan bahwa variabel SP, TI, TD, dan TR memiliki hubungan yang positif dan signifikan (sig. $<0,05$ ) sebagaimana disajikan pada Tabel 3. Variabel SP dan TI memiliki hubungan yang positif dengan tingkat hubungan kuat $(\mathrm{r}=0,762)$. Artinya, varians yang terjadi pada variabel TI, sebesar 76,2 persen dapat dijelaskan oleh varians variabel SP (H1 diterima). Selanjutnya, variabel SP dan TD memiliki hubungan yang positif dengan tingkat hubungan kuat $(r=0,729)$. Artinya, varians yang terjadi pada variabel $\mathrm{TD}$, sebesar 72,9 persen dapat dijelaskan oleh varians variabel SP (H2 diterima). Sementara itu, variabel SP dan TR memiliki hubungan yang positif dengan tingkat hubungan kuat $(r=0,640)$. Artinya, varians yang terjadi pada variabel TR, sebesar 64,0 persen dapat dijelaskan oleh varians variabel SP (H3 diterima). Selanjutnya, variabel TI dan TD memiliki hubungan yang positif dengan tingkat hubungan sangat kuat ( $\mathrm{r}=$ 0,800 ). Artinya, varians yang terjadi pada variabel TD, sebesar 80,0 persen dapat dijelaskan oleh varians variabel TI (H4 diterima). Variabel TI dan TR memiliki hubungan yang positif dengan tingkat hubungan kuat $(r=0,735)$. Artinya, varians yang terjadi pada variabel $\mathrm{TR}$, sebesar 73,5 persen dapat dijelaskan oleh varians variabel TI (H5 diterima). Sementara itu, variabel TD dan TR memiliki hubungan yang positif dengan tingkat hubungan kuat $(\mathrm{r}=0,735)$. Artinya, varians yang terjadi pada variabel TR, sebesar 73,5 persen dapat dijelaskan oleh varians variabel TD (H6 diterima).

\section{Persepsi Pegawai Terhadap Implementasi Manajemen Talenta di Kementerian Keuangan}

Hasil pengolahan data, didapat hasil sebagaimana pada Tabel 4. Terdapat beberapa indikator yang perlu dianalisis, yaitu indikator yang memiliki rataan di bawah 3,78 dan persentase tidak setuju di atas 10 persen (two boxes). Indikator-indikator tersebut adalah pemahaman 9 boks pemetaan pegawai (TI2), organisasi mencari orang berbakat untuk menempati posisi penting dalam organisasi (TI5), tersedia informasi terbuka tentang kriteria pegawai yang ditetapkan menjadi talent (TI6), tersedia informasi terbuka tentang pegawai yang ditetapkan menjadi talent (TI7), motivasi pimpinan untuk pengembangan karir (TD1), pimpinan menilai kebutuhan pengembangan karir secara objektif (TD2), dan fasilitas program pengembangan untuk meningkatkan kompetensi (TD5).

Pemahaman 9 boks pemetaan pegawai (TI2)

Responden mengatakan bahwa unit eselon I perlu untuk melakukan diseminasi atau sosialisasi terkait manajemen talenta kepada seluruh pegawai karena masih banyak pegawai yang belum memahami manajemen talenta. Pegawai yang diusulkan menjadi talent, sebelumnya dilakukan pemetaan pegawai melalui pengukuran kompetensi dan penilaian kinerja. Pengukuran kompetensi/potensi diperoleh dari hasil pelaksanaan assessment center atau hasil psikotes. Sementara itu, pengukuran kinerja diperoleh berdasarkan Nilai Kinerja Pegawai (NKP). Selanjutnya, nilai kompetensi/potensi dan NKP berdasarkan kategori yang telah ditetapkan disusun ke dalam boks pemetaan pegawai untuk setiap jabatan yang terdiri dari 9 boks. Calon talent merupakan pegawai yang berada pada boks 9 pemetaan pegawai serta dapat menambahkan calon talent yang berada pada boks 8 dan 7 berdasarkan surat keputusan pimpinan unit Eselon I yang akan disampaikan dalam forum pimpinan (Kemenkeu, 2013).

Tabel 3. Hubungan antara variabel SP, TI, TD, dan TR

\begin{tabular}{llcccc}
\hline & & Total_SP & Total_TI & Total_TD & Total_TR \\
\hline Total_SP & Pearson Correlation & 1 & $.762^{* *}$ & $.729^{* *}$ & $.640^{* *}$ \\
& Sig. (2-tailed) & & .000 & .000 & .000 \\
Total_TI & Pearson Correlation & $.762 * *$ & 1 & $.800^{* *}$ & $.654^{* *}$ \\
& Sig. (2-tailed) & .000 & & .000 & .000 \\
Total_TD & Pearson Correlation & $.729 * *$ & $.800^{* *}$ & 1 & $.735^{* *}$ \\
& Sig. (2-tailed) & .000 & .000 & .000 \\
Total_TR & Pearson Correlation & $.640 * *$ & $.654^{* *}$ & $.735^{* *}$ & .000 \\
& Sig. (2-tailed) & .000 & .000 & .000 & 1 \\
\hline
\end{tabular}

**. Correlation is significant at the 0.01 level (2-tailed); $N=408$ 
Tabel 4. Rataan dan two boxes indikator penelitian

\begin{tabular}{llccc}
\hline \multirow{2}{*}{ Simbol } & \multicolumn{1}{c}{ Indikator } & \multicolumn{3}{c}{ Two boxes } \\
\cline { 3 - 5 } & & Rataan & $\begin{array}{c}\text { Setuju } \\
(\%)\end{array}$ & $\begin{array}{c}\text { Tidak } \\
\text { Setuju (\%) }\end{array}$ \\
\hline SP1 & Strategi manajemen talenta (MT) mengacu pada tujuan organisasi & 3,60 & 91 & 9 \\
SP2 & Strategi MT sesuai dengan budaya organisasi & 4,12 & 98 & 2 \\
SP3 & Strategi MT sesuai dengan proses bisnis organisasi & 4,15 & 97 & 3 \\
TI1 & Penilaian talent memanfaatkan alat penilaian yang tersedia & 3,61 & 90 & 10 \\
TI2 & Pemahaman 9 boks pemetaan pegawai & 3,09 & 70 & 30 \\
TI3 & Pimpinan memahami kinerja pegawai untuk bertransformasi & 4,08 & 97 & 3 \\
TI4 & Perencanaan talent telah dipersiapkan tahun sebelumnya & 3,94 & 90 & 10 \\
TI5 & Organisasi mencari orang berbakat untuk menempati posisi penting dalam & 3,55 & 88 & 13 \\
& organisasi & & & \\
TI6 & Tersedia informasi terbuka tentang kriteria pegawai yang ditetapkan menjadi & 3,25 & 77 & 23 \\
& talent & & & \\
TI7 & Tersedia informasi terbuka tentang pegawai yang ditetapkan menjadi talent & 3,51 & 79 & 21 \\
TD1 & Motivasi pimpinan untuk pengembangan karir & 3,45 & 85 & 15 \\
TD2 & Pimpinan menilai kebutuhan pengembangan karir secara objektif & 3,52 & 85 & 15 \\
TD3 & Pimpinan mendorong pembelajaran & 4,23 & 98 & 2 \\
TD4 & Tersedia mentor untuk pengembangan kompetensi tertentu & 3,70 & 87 & 13 \\
TD5 & Fasilitas program pengembangan untuk meningkatkan kompetensi & 3,68 & 88 & 12 \\
TD6 & Pimpinan mendorong pengembangan karir & 4,20 & 99 & 1 \\
TR1 & Organisasi menghargai kinerja & 4,08 & 97 & 3 \\
TR2 & Penghargaan yang diberikan sesuai dengan kinerja & 3,67 & 91 & 9 \\
TR3 & Tetap bertahan untuk waktu yang lama pada unit saat ini & 4,00 & 91 & 9 \\
TR4 & Semakin termotivasi untuk berkontribusi pada unit & 4,20 & 97 & 3 \\
\hline & Rata-rata nilai & 3,78 & 90 & 10 \\
\hline
\end{tabular}

Hasil pemetaan pegawai berguna dalam meningkatkan kinerja pegawai yang pada akhirnya akan menghasilkan daya saing dan kinerja organisasi yang lebih baik. Selain itu, pemetaaan pegawai ini memiliki beberapa implikasi terhadap banyak aspek, seperti analisis pekerjaan dan identifikasi keterampilan untuk setiap peran, pengembangan keterampilan, standar pengembangan, intervensi pengembangan kemampuan, penilaian kinerja, dan peningkatan kinerja. Semua faktor tersebut berdampak pada kinerja karyawan dan perusahaan (Mittal et al. 2019).

Organisasi mencari orang berbakat untuk menempati posisi penting dalam organisasi (TI5)

Responden masih menganggap bahwa unit eselon I belum mencari orang-orang berbakat untuk menempati posisi penting pada organisasi. Proses untuk menentukan talent dimulai dari seleksi adminitrasi, yaitu dari segi pangkat/golongan, kinerja, dan kompetensi. Pegawaipegawai yang memenuhi persyaratan ini dan masuk ke dalam boks 7,8, dan 9 maka akan diusulkan untuk menjadi talent dan masuk ke dalam daftar panjang (long list) yang selanjutnya diserahkan kepada satuan kerja masing-masing. Dari long list tadi akan mengerucut menjadi short list untuk selanjutnya akan dilakukan rapat pimpinan. Dari hasil rapat pimpinan ini akan diperoleh pegawai yang masuk ke dalam talent pool untuk selanjutnya dilakukan proses pengembangan dan retensi talent. Pada akhirnya akan diperoleh talent yang masuk kategori ready now (siap untuk promosi atau menduduki jabatan strategis), need improvement (masih memerlukan pengembangan), dan exit (keluar dari talent pool) (Kemenkeu, 2017).

Ali et al. (2019) mengungkapkan bahwa strategi manajemen talenta terdiri dari menarik (attracting), mengembangkan (developing), dan mempertahankan (retaining). Perekrutan dilakukan dengan strategi yang tepat akan mendapatkan talenta terbaik bagi organisasi yang akan meningkatkan pertumbuhan dan kesuksesan organisasi (Vincent, 2019). Program pengembangan yang meliputi training, coaching, mentoring, on the job training, job enrichment, dan job enlargement 
dimaksudkan untuk mempercepat pembelajaran karyawan (Ali et al. 2019). Sementara itu, terkait program retensi, organisasi dapat memberikan peluang untuk lebih baik, kompensasi, dan keamanan kerja (Oladapo, 2014).

Tersedia informasi terbuka tentang kriteria pegawai dan pegawai yang ditetapkan menjadi talent (TI6 dan TI7)

Responden memberikan masukan bahwa mereka tidak mengetahui kriteria menjadi talent. Responden merasa kurangnya transparansi kriteria talent dan pegawai yang menjadi talent. Responden menyatakan bahwa sebaiknya organisasi menyediakan fasilitas yang mudah diakses terkait dengan manajemen talenta baik terkait persyaratan maupun informasi terkait pegawai yg sudah masuk dalam program manajemen talenta. Selain itu, daftar talent perlu diumumkan sehingga pegawai lainnya dapat mengambil contoh sikap, perilaku, dan etos kerja dari para talent tersebut, serta memicu semangat pegawai.

Kemenkeu (2017) menjelaskan bahwa salah satu asas dalam manajemen talenta adalah terbuka. Hal ini berarti informasi manajemen talenta yang meliputi tahapan pelaksanaan, kriteria, dan informasi mengenai pegawai yang ditetapkan menjadi talent yang dapat diakses melalui laman oleh seluruh pegawai. Argenti (2017) menyatakan bahwa suatu organisasi membutuhkan komunikasi internal antara atasan dengan bawahan untuk menjaga hubungan agar saling terbuka dalam hal pekerjaan. Partisipasi dianggap penting untuk menjaga keterlibatan karyawan di semua tingkat organisasi tanpa mengedepankan tanggung jawab pekerjaan. Selain itu, partisipasi dapat mendorong kekompakan antara sesama karyawan maupun dengan atasan (Agustini dan Purnaningsih, 2018). Selain itu, Permana et al. (2011) mengatakan bahwa komunikasi melalui sarana komunikasi yang memadai akan membantu organisasi untuk membangun keterikatan dan retensi pegawai.

\section{Motivasi pimpinan untuk pengembangan karir (TD1)}

Responden masih menganggap bahwa unit eselon I mereka belum optimal dalam memberikan motivasi melalui umpan balik terbaru untuk tujuan pengembangan kariernya. Dewi (2020) menjelaskan bahwa manajemen talenta sebagai salah satu alat manajemen yang strategis dan diimplementasikan secara berkelanjutan, membutuhkan komitmen pimpinan terus menerus dalam jangka panjang. Pengelolaan talenta yang baik mampu meningkatkan keuntungan non-finansial seperti daya tarik perusahaan dan motivasi karyawan, serta dapat memberikan dampak yang tinggi dan keuntungan perusahaan secara signifikan (Rachmawati, 2012). Selain itu, gaya kepemimpinan yang baik akan meningkatkan motivasi kerja, komitmen organisasi, dan kinerja (Fabio et al. 2016). Ali et al. (2019) menjelaskan bahwa karyawan yang bertalenta lebih tertarik kepada perusahaan yang menghargai dan memberikan kesempatan untuk maju bagi karyawannya. Berdasarkan kinerja, melalui umpan balik yang aktif sepanjang tahun, baik itu top-down maupun bottom-up, mampu menutup kesenjangan kemampuan bisnis. Permana et al. (2011) menjelaskan bahwa pemberian kesempatan yang sama untuk pengembangan kompetensi diri karyawan dapat membantu membangun employee engangement dan employee retention.

Pimpinan menilai kebutuhan pengembangan karir secara objektif (TD2)

Responden menganggap bahwa pimpinan di eselon I mereka belum melakukan penilaian secara objektif terhadapkebutuhan pengembangankarirpegawai.Pasha et al. (2017) menjelaskan bahwa praktik pengembangan karir karyawan memiliki hubungan positif dengan komitmen karir dan kesuksesan karir dan bagaimana efikasi diri mempengaruhi kesuksesan karir. Ali et al. (2019) menjelaskan bahwa semua karyawan memiliki kesempatan dan pengakuan serta penilaian berdasarkan bukti (Judgement Drive Individual). Permana et al. (2011) juga menjelaskan bahwa pemberian kesempatan yang sama untuk pengembangan karir diri karyawan dapat membantu membangun employee engangement dan employee retention. Selain itu, dengan pola karir, kualifikasi jabatan, entry point, dan batasan karir yang tepat akan menghasilkan perencanaan karir yang baik bagi individu (Abeng et al. 2016)

Fasilitas program pengembangan untuk meningkatkan kompetensi (TD5)

Responden menganggap bahwa program pengembangan kompetensi yang saat ini disediakan organisasi belum sepenuhnya mampu untuk meningkatkan kompetensi pegawai. Ali et al. (2019) dalam penelitiannya mengatakan bahwa perusahaan memberikan kesempatan dan melihat bahwa semua karyawan merupakan talent dan harus dikembangkan. 
Melalui Individual Development Plan (IDP), karyawan dapat mengisi rencana pengembangan diri, baik karakter, kemampuan, komitmen, maupun harapan untuk jangka pendek, menengah, maupun panjang. Responden juga memberikan masukan bahwa mereka ingin diberikan kesempatan yang lebih luas lagi untuk mendapatkan pelatihan yang mendukung kemampuan teknis. Selain itu, program coaching, mentoring atau counseling untuk dapat dilakukan secara konsisten dan berkesinambungan. Terkait dengan program pengembangan talent, responden menyarankan agar dapat dilakukan dengan alokasi waktu yang lebih panjang, yaitu minimal 3 bulan. Selain itu, organisasi perlu memperhatikan kesenjangan kompetensi dengan kebutuhan industri 4.0, kepercayaan stakeholders, dan nilai, cara bekerja, dan mindset (Hidayat et al. 2020).

Program pengembangan talent merupakan kesempatan dan kegiatan yang menunjang peningkatan kompetensi, pengetahuan, dan keahlian baru yang dilaksanakan secara simultan, di mana talent tetap melaksanakan tugas rutin sesuai dengan bidang tugasnya. Program ini merupakan sinergi dari metode on-the-job training (non-class) dan metode off-the-job training (onclass). Metode off-the-job training dilakukan oleh beberapa unit eselon I melalui kerja sama dengan BPPK. Pelatihan yang dilakukan ini bertujuan untuk membekali para talent terkait pengembangan delapan kompetensi manajerial dan satu kompetensi sosiokultural. Kedepannya diharapkan seluruh pelatihan terkait pengembangan talent oleh unit eselon I dapat dilakukan oleh BPPK supaya memiliki standar yang sama (Kemenkeu, 2017).

\section{Hubungan antara Profil Responden dengan Variabel Penelitian}

Variabel penelitian difokuskan pada tujuh indikator, yaitu pemahaman 9 boks pemetaan pegawai (TI2), organisasi mencari orang berbakat untuk menempati posisi penting dalam organisasi (TI5), tersedia informasi terbuka tentang kriteria pegawai yang ditetapkan menjadi talent (TI6), tersedia informasi terbuka tentang pegawai yang ditetapkan menjadi talent (TI7), motivasi pimpinan untuk pengembangan karier (TD1), pimpinan menilai kebutuhan pengembangan karier secara objektif (TD2), dan fasilitas program pengembangan untuk meningkatkan kompetensi (TD5). Berdasarkan hasil pengolahan data, didapatkan hasil sebagaimana Tabel 5.
Berdasarkan Tabel 5, dijelaskan bahwa terdapat hubungan antara profil responden dengan indikator penelitian (Asymp. Sig < 5\%). Indikator pemahaman 9 boks pemetaan pegawai (TI2) memiliki hubungan dengan profil unit eselon I, kedudukan/jabatan, lokasi kantor, dan jenis kelamin. Indikator organisasi mencari orang berbakat untuk menempati posisi penting dalam organisasi (TI5) memiliki hubungan dengan profil unit eselon I dan kedudukan/jabatan. Indikator tersedia informasi terbuka tentang kriteria pegawai yang ditetapkan menjadi talent (TI6) memiliki hubungan dengan profil unit eselon I. Indikator tersedia informasi terbuka tentang pegawai yang ditetapkan menjadi talent (TI7) memiliki hubungan dengan profil unit eselon I, pendidikan terakhir, dan jenis kelamin. Indikator motivasi pimpinan untuk pengembangan karier (TD1) memiliki hubungan dengan profil kedudukan/jabatan. Indikator pimpinan menilai kebutuhan pengembangan karier secara objektif(TD2) memiliki hubungan dengan profil unit eselon I dan kedudukan/jabatan. Sementara itu, indikator fasilitas program pengembangan untuk meningkatkan kompetensi (TD5) tidak memiliki hubungan dengan profil responden.

\section{Perbedaan Persepsi antara Profil Responden dengan Variabel Penelitian}

Variabel penelitian difokuskan pada tujuh indikator, yaitu pemahaman 9 boks pemetaan pegawai (TI2), organisasi mencari orang berbakat untuk menempati posisi penting dalam organisasi (TI5), tersedia informasi terbuka tentang kriteria pegawai yang ditetapkan menjadi talent (TI6), tersedia informasi terbuka tentang pegawai yang ditetapkan menjadi talent (TI7), motivasi pimpinan untuk pengembangan karier (TD1), pimpinan menilai kebutuhan pengembangan karier secara objektif (TD2), dan fasilitas program pengembangan untuk meningkatkan kompetensi (TD5).

Hasil analisis dengan menggunakan uji T-Test, didapatkan hasil bahwa tidak ada perbedaan persepsi antara responden laki-laki dan perempuan terhadap indikator-indikatoryang dianalisis. Sementara itu, untuk profil lokasi kantor responden disesuaikan menjadi Jawa dan Luar Jawa sehingga didapat hasil bahwa terdapat perbedaan persepsi terhadap indikator tersedia informasi terbuka tentang pegawai yang ditetapkan menjadi talent (TI7). Responden yang lokasi kantornya di Jawa (rataan= 3,44) memiliki persepsi yang lebih rendah dibandingkan dengan responden yang lokasi kantornya di luar Jawa (rataan= 3,89 ). 
Tabel 5. Hasil analisis tabulasi silang profil responden dengan indikator penelitian

\begin{tabular}{lccccccc}
\hline \multirow{2}{*}{\multicolumn{1}{c}{ Profil responden }} & \multicolumn{7}{c}{ Asymp. Sig (2-sided) Chi-Square Test } \\
\cline { 2 - 8 } & TI2 & TI5 & TI6 & TI7 & TD1 & TD2 & TD5 \\
\hline Unit eselon I & 0,000 & 0,000 & 0,001 & 0,000 & 0,071 & 0,020 & 0,089 \\
Kedudukan/jabatan & 0,000 & 0,039 & 0,335 & 0,939 & 0,021 & 0,047 & 0,123 \\
Tahun kelahiran & 0,072 & 0,067 & 0,144 & 0,333 & 0,459 & 0,103 & 0,560 \\
Lokasi kantor & 0,011 & 0,273 & 0,196 & 0,101 & 0,356 & 0,053 & 0,126 \\
Pendidikan terakhir & 0,071 & 0,330 & 0,542 & 0,028 & 0,787 & 0,898 & 0,491 \\
Jenis kelamin & 0,022 & 0,201 & 0,160 & 0,035 & 0,174 & 0,121 & 0,670 \\
\hline
\end{tabular}

Hasil tes ANOVA menunjukkan bahwa terdapat perbedaan signifikan berdasarkan pendidikan terakhir. Lebih lanjut, dengan menggunakan Tukey Post Hoc ditujukkan bahwa responden dengan latar belakang pendidikan D3 (rataan= 2,80) memiliki perbedaan persepsiyang lebih rendah terhadap indikator pemahaman 9 boks pemetaan pegawai (TI2) dibandingkan dengan responden dengan latar belakang pendidikan S2 (rataan= 3,36). Sementara itu, responden dengan latar belakang S2 $($ rataan $=3,42)$ dan $\mathrm{S} 2 /$ Sederajat (rataan $=3,47)$ memiliki perbedaan persepsi yang lebih rendah terhadap indikator tersedia informasi terbuka tentang pegawai yang ditetapkan menjadi talent (TI7) dibandingkan dengan responden dengan latar belakang D1 (rataan=4,41).

Berdasarkan unit eselon I, dilakukan pengklasifikasian ulang menjadi tiga klasifikasi, yaitu DJP, BPPK, serta selain DJP dan BPPK. Berdasarkan uji ANOVA dan Tukey Post Hoc, didapatkan hasil bahwa responden dari DJP (rataan= 3,34) memiliki perbedaan persepsi yang lebih rendah terhadap indikator organisasi mencari orang berbakat untuk menempati posisi penting dalam organisasi (TI5) dibandingkan dengan responden dari BPPK (rataan= 3,68) dan selain DJP dan BPPK (rataan= 3,77 ). Responden yang berasal dari DJP (rataan=3,47) memiliki perbedaan persepsi yang lebih tinggi terhadap indikator tersedia informasi terbuka tentang kriteria pegawai yang ditetapkan menjadi talent (TI6) dibandingkan dengan responden yang berasal dari selain DJP. Responden yang berasal dari DJP (rataan=4,15) memiliki perbedaan persepsi yang lebih tinggi terhadap indikator tersedia informasi terbuka tentang pegawaiyang ditetapkan menjadi talent (TI7) dibandingkan dengan responden yang berasal dari selain DJP. Sementara itu, responden yang berasal dari DJP (rataan=3,37) memiliki perbedaan persepsi yang lebih rendah terhadap indikator pimpinan menilai kebutuhan pengembangan karier secara objektif (TD2) dibandingkan dengan responden yang berasal dari BPPK (rataan=3,66).
Berdasarkan tahun kelahiran, didapat hasil bahwa responden yang lahir tahun 1970-1980 (rataan=3,33) dan 1980-1986 (rataan=3,26) memiliki perbedaan persepsiyanglebihtinggiterhadapindikatorPemahaman pegawai terhadap 9 (sembilan) boks pemetaan pegawai (TI2) dibandingkan dengan responden yang lahir tahun 1987-1994 (rataan=2,87). Responden yang lahir tahun 1987-1994 (rataan=3,41) memiliki perbedaan persepsi yang lebih rendah terhadap indikator organisasi mencari orang berbakat untuk menempati posisi penting dalam organisasi (TI5) dibandingkan dengan responden yang lahir tahun di atas 1994 (rataan= 4,00). Responden yang lahir tahun 1970-1979 (rataan=3,50) memiliki perbedaan persepsi yang lebih tinggi terhadap indikator tersedia informasi terbuka tentang kriteria pegawai yang ditetapkan menjadi talent (TI6) dibandingkan dengan responden yang lahir tahun 1987-1994 (rataan=3,03). Sementara itu, responden yang lahir tahun 1987-1994 (rataan=3,28) memiliki perbedaan persepsi yang lebih rendah terhadap indikator Unit saya memotivasi saya dengan umpan balik terbaru untuk tujuan pengembangan karier saya (TD1) dibandingkan dengan responden yang lahir tahun di atas 1994 (rataan=3,88).

Selanjutnya, berdasarkan kedudukan/jabatan, didapat hasil bahwa responden dengan kedudukan jabatan eselon II dan III (rataan= 4,11) serta eselon IV (rataan= 3,67 ) memiliki perbedaan persepsi yang lebih tinggi terhadap indikator Pemahaman pegawai terhadap 9 (sembilan) boks pemetaan pegawai (TI2) dibandingkan dengan responden non-pejabat struktural (rataan $=2,98$ ). Sementara itu, responden dengan kedudukan jabatan eselon IV (rataan=3,60) memiliki perbedaan persepsi yang lebih tinggi terhadap indikator tersedia informasi terbuka tentang kriteria pegawai yang ditetapkan menjadi talent (TI6) dibandingkan dengan responden non-pejabat struktural (rataan $=3,19)$. 


\section{Implikasi Manajerial}

Dalam mengembangkan manajemen talenta, pengelola manajemen talenta dapat mempertimbangkan faktorfaktor berikut:

Melakukan sosialisasi terkait manajemen talenta kepada seluruh pegawai

Sosialisasi yang baik akan mendukung keberhasilan proses manajemen talenta. Bentuk komunikasi dapat dilakukan dengan membangun laman, peraga, sosialisasi, diklat dll. Selain itu, pengelola manajemen talenta perlu bersinergi dengan unit yang mengelola kepegawaian pusat untuk mengintegrasikan informasi posisi pegawai dengan sistem informasi kepegawaian. Alietal. (2019) dalam penelitiannya tentang manajemen talent di PT. Unilever Indonesia Tbk. menjelaskan bahwa proses komunikasi perlu melibatkan semua pihak sehingga dapat dipastikan semua informasi terkait manajemen talenta tersebut efektif, strategis, dan terintegrasi.

Memfasilitasi program pengembangan untuk meningkatkan kompetensi dan karir

Yuniarto et al. (2019) dalam penelitiannya tentang transformasi corporate university di Kementerian Keuangan menjelaskan bahwa program pengembangan kompetensi dan karir pegawai dapat dilakukan melalui formal learning, social learning, dan experiental learning. Pegawai diberikan formulir Individual Development Program (IDP) yang diisi rencana pengembangan kompetensi dan karir mereka, baik untuk jangka pendek, menengah, maupun jangka panjang. Formal learning yang relevan, dapat diterapkan, dapat diakses, dan berdampak. Social learning dapat dilakukan melalui program coaching, mentoring atau counseling secara konsisten dan berkesinambungan. Selain itu, experiental learning dapat dilakukan dengan memberikan tugas yang menantang, action learning dari formal learning yang didapat, serta pertukaran pegawai (secondment), baik di lingkungan kementerian maupun swasta. Melalui program-program ini, diharapkan mampu memberikan pengaruh positif terhadap kinerja karyawan dan perilaku karir proaktif. Program pengembangan ini dapat meningkatkan bakat dan keterampilan, kinerja, kepuasan, motivasi, keterlibatan, serta retensi pegawai (Wong et al. 2017).
Memperhatikan profil responden

Hal ini menjadi penting karena responden memiliki karakteristik yang berbeda baik dari segi jenis kelamin, lokasi kantor, kedudukan/jabatan, tahun kelahiran, unit eselon I, dan pendidikan terakhir. Hal ini dikarenakan terdapat hubungan dan perbedaan persepsi antara profil responden dengan indikator-indikator yang dianalisis. Oleh karena itu, pihak manajemen harus mengembangkan manajemen talenta yang tepat untuk memfasilitasi para pegawainya.

\section{KESIMPULAN DAN SARAN}

\section{Kesimpulan}

Persepsi pegawai terhadap implementasi manajemen talenta di Kementerian Keuangan sudah baik, tetapi terdapat 7 indikator yang perlu dilakukan perbaikan. Perbaikan difokuskan pada (1) pemahaman tentang 9 boks pemetaan pegawai, (2) pencarian orang-orang bertalenta oleh organisasi, (3) informasi tentang kriteria menjadi talent, (4) informasi tentang pegawai yang ditetapkan menjadi talent, (5) motivasi pimpinan untuk mengembangkan karier pegawai, (6) penilaian pengembangan karier secara objektif, serta (7) fasilitas program pengembangan kompetensi pegawai.

Hubungan korelasi antarvariabel menunjukkan bahwa variabel strategic workforce planning, talent identification, talent development, dan talent retention memiliki hubungan yang positif dan kuat. Selain itu, profil responden yang meliputi jenis kelamin, kedudukan/jabatan, tahun kelahiran, unit eselon I, domisili kantor, serta pendidikan terakhir memiliki hubungan dengan tujuh indikator di atas.

Indikator pemahaman 9 boks pemetaan pegawai (TI2) dipersepsikan berbeda oleh profil responden yang terdiri dari pendidikan terakhir, tahun kelahiran, serta kedudukan/jabatan. Indikator organisasi mencari orang berbakat untuk menempati posisi penting dalam organisasi (TI5) dipersepsikan berbeda oleh profil responden yang meliputi unit eselon I dan tahun kelahiran. Indikator tersedia informasi terbuka tentang kriteria pegawai yang ditetapkan menjadi talent (TI6) dipersepsikan berbeda oleh profil responden unit eselon I, tahun kelahiran, dan kedudukan/jabatan. Indikator tersedia informasi terbuka tentang pegawai yang ditetapkan menjadi talent (TI7) dipersepsikan 
berbeda oleh profil responden, yaitu lokasi kantor, pendidikan terakhir, dan unit eselon I. Indikator motivasi pimpinan untuk pengembangan karier (TD1) dipersepsikan berbeda oleh profil responden tahun kelahiran. Sementara itu, indikator pimpinan menilai kebutuhan pengembangan karier secara objektif (TD2) dipersepsikan berbeda oleh profil responden unit eselon I.

\section{Saran}

Dalam melaksanakan manajemen talenta, organisasi perlu melakukan komunikasi kepada seluruh pegawai terkait manajemen talenta melalui sosialisasi, diseminasi, pelatihan, atau pembuatan laman yang dapat diakses seluruh pegawai. Selain itu, pimpinan perlu memotivasi pegawai dalam pengembangan karir dan kompetensi para pegawai sehingga diperoleh calon pemimpin yang merupakan bakat terbaik organisasi yang pada akhirnya akan mendukung visi dan misi organisasi dalam jangka panjang. Penelitian selanjutnya dapat menganalisis pengaruh profil responden terhadap kesuksesan manajemen talenta. Selain itu, dapat dianalisis bagaimana pengaruh implementasi manajemen talenta terhadap keterlibatan, retensi, dan kinerja pegawai. Objek penelitian dapat dilakukan baik di sektor pemerintah maupun swasta.

\section{DAFTAR PUSTAKA}

Abeng AT, Syarief R, Suroso AI. 2016. Perencanaan karir pegawai di Badan Pertanahan Nasional RI. Jurnal Aplikasi Bisnis dan Manajemen 2 (3): 239-247.

Agustini NA, Purnaningsih N. 2018. Pengaruh komunikasi internal dalam membangun budaya organisasi. Jurnal Komunikasi Pembangunan 16(1): 89-108. https://doi. org/10.46937/16201825198.

Argenti PA. 2017. Strategic Communication in the C-Suite. International Journal of Business Communication 54(2): 146-160. DOI: $10.1177 / 2329488416687053$.

Amrhein V, Trafimow D, Greenland S. 2019. Inferential statistics as descriptive statistics: there is no replication crisis if we don't expect replication. The American Statistician 73(10): 262-270. DOI: $10.1080 / 00031305.2018 .1543137$

Ali AS, Hermawan A, Asnawi YH. 2019. Konsep dan tantangan dalam implementasi talent management di perusahaan multinasional: studi kasus PT Unilever Indonesia Tbk. Jurnal Manajemen Teori dan Terapan 12(1): 1-17.

Anggelina J, Japarianto E. 2014. Analisis pengaruh sikap, subjective norm dan perceived behavioral control terhadap purchase intention pelanggan SOGO Departement Store di Tunjungan Plaza Surabaya. Jurnal Strategi Pemasaran 2(1): 1-7.

Betz Cecily L. 2019. Generations X, Y, and Z. Journal of Pediatric Nursing 44: A7-A8.

Cappelli P, Keller JR. 2014. Talent management: conceptual approaches and pratical challenges. Annual Review of Organizational Psychology and Organizational Behavior 1(1):305-331.

Dewi Ida Ayu Rai Sri. 2020. Manajemen talenta dalam mewujudkan pemimpin berkinerja tinggi. Jurnal Good Governance 16(1): 49-68.

Fabio Bagus Putu, Hubeis Musa, Puspitawati Herien. 2016. Pengaruh gaya kepemimpinan, motivasi kerja terhadap komitmen organisasi yang berimplikasi pada kinerja karyawan. Jurnal Aplikasi Bisnis dan Manajemen 2 (1): 91-104.

Farooq Miiro, Othman Azam, Nordin Mohamad Sahari, Ibrahim Mohd Burhan. 2016. A measurement model of talent management practices among university staff in central region of Uganda. Journal of Positive Management 7(3): 3-19.

Hidayat N, Hubeis M, Sukmawati A, Eriyatno. 2020. Model pengelolaan sumberdaya manusia berbasis kompetensi era industri 4.0. Jurnal Aplikasi Bisnis dan Manajemen 6(3): 501-513.

[Kemenkeu] Kementerian Keuangan. 2013. Keputusan Menteri Keuangan Nomor 130/KMK.01/2013 tentang Penataan Pegawai di Lingkungan Kementerian Keuangan. Jakarta: Kemenkeu.

[Kemenkeu] Kementerian Keuangan. 2016. Peraturan Menteri Keuangan Nomor 60/PMK.01/2016 Tentang Manajemen Talenta Kementerian Keuangan. Jakarta: Kemenkeu.

[Kemenkeu] Kementerian Keuangan. 2017. Peraturan Menteri Keuangan Nomor 161/PMK.01/2017 Tentang Perubahan atas Peraturan Menteri Keuangan Nomor 60/PMK.01/2016 Tentang Manajemen Talenta Kementerian Keuangan. Jakarta: Kemenkeu.

Komara E. 2019. Kompetensi profesional pegawai ASN (Aparatur Sipil Negara) di Indonesia. Mimbar Pendidikan: Jurnal Indonesia untuk Kajian Pendidikan 4(1): 73-84.

Mehta A. 2011. Human capital management: a comprehensive approach to augment 
organizational performance. Review of Management 1(2): 44-57.

Mishra P, Singh U, Pandey CM. 2019. Application of student's $t$-test, analysis of variance, and covariance. Annals of cardiac anaesthesia 22(4): 407-411. DOI: 10.4103/aca.ACA_94_19

Mittal A, Dhiman R, Lamba P. 2019. Skill mapping for blue-collar employees and organisational performance. Benchmarking 26(4): 1255-1274. DOI: 10.1108/BIJ-08-2018-0228

Mudzakir. 2020. Smart ASN menguasai era digital. https://www.menpan.go.id/site/berita-terkini/ smart-asn-menguasai-era-digital. [3 Agu 2020].

Nair K. 2019. Overcoming today's digital talent gap in organizations worldwide. Development and Learning in Organizations. 33(6): 16-18.

Oberer B, Erkollar A. 2018. Leadership 4.0: Digital leaders in the age of industry 4.0. International Journal of Organizational Leadership 7(4):404412.

Oladapo V. 2014. The impact of talent management on retention. Journal of Business Studies Quartely 5(3): 1-19.

Pasha AT, Hamid KA, Shahzad A. 2017. Moderating effect of self-efficacy and impact of career development practices on career success under the mediating role of career commitment in the insurance sector of Pakistan. Journal of Internet Banking and Commerce 22(1): 1-22.
Pella DA, Inayati A. 2011. Talent Management, Mengembangkan SDM untuk Mencapai Pertumbuhan dan Kinerja Prima. Jakarta: PT. Gramedia Pustaka Utama.

Permana NIK, Jalal OM, Martono FXS, Harnoko L, Bataona J, Achirina. 2011. Talent Management Implementation: Belajar dari PerusahaanPerusahaan Terkemuka. Jakarta: PPM Manajemen.

Rachmawati M. 2012. Strategi untuk menerapkan talent management (manajemen talenta) dalam perusahaan. International Journal of Management, Economics and Social Sciences 1(2):33-41.

Sugiyono. 2017. Statistika untuk Penelitian. Bandung: Alfabeta.

Vincent V. $2019.360^{\circ}$ recruitment:A Aolistic recruitment process. Strategic HR Review. 18(3): 128-132. DOI: 10.1108/SHR-02-2019-0006

Wong Silky SK., Cross Jennifer A. Mueller Phillip S. 2017. Impact of mentoring on practicing engineers: a meta-synthesis. Journal of Workplace Learning 30 (6): 415-441.

Yuniarto A, Hubeis AV, Sukmawati A. 2019. Faktorfaktor kunci kesuksesan implementasi corporate university dalam rangka transformasi Badan Pendidikan dan Pelatihan Keuangan. Jurnal Aplikasi Bisnis dan Manajemen 5(3): 466-477. 